\title{
Root turnover and productivity of coniferous forests
}

\author{
R. FOGEL \\ Herbarium, University of Michigan, Ann Arbor, MI, USA
}

\section{Key words Ecosystem Mycorrhiza Root biomass}

\begin{abstract}
Summary Fine roots and mycorrhizae have recently been shown to produce a major portion of the organic matter entering decomposition. Roots and mycorrhizae constitute 63 to $70 \%$ of total net primary production in Douglas-fir and Pacific silver fir stands. The importance of roots in primary production makes the method of root extraction from the soil important. Wet-sieving with small mesh screens is more effective than hand-sorting for fine roots and mycorrhizae. Screen size, the efficiency of recovery, the physiological status of the roots and conversion factors to derive biomass from the numbers of root tips should be stated. Published data is enhanced if the phenological status of the stand, its age, tree density, and soil texture are quoted.

Given the large fluxes in fine root and mycorrhiza populations, single biomass estimates are not useful in studies of ecosystem struct ure and function. A better understanding needs accurate methods to distinguish live and dead roots, data on the production and turnover of large roots, and data on the transfer of nutrients accompanying the large input of roots to decomposition.
\end{abstract}

\section{Introduction}

The role of roots and mycorrhizae in the primary production and mineral nutrition of coniferous forests is attracting increased attention. The exclusion of mycorrhizae, until recently, reflects the problems in separating them from soil and studying them in situ. Data on the belowground ecosystem is needed to extrapolate to field conditions information on ion uptake and translocation, and respiration.

This review examines the contribution of roots (mycorrhizal and nonmycorrhizal) to the productivity of coniferous forests, provides information on the efficiency of two methods for estimating root biomass, and compares three methods of calculating root turnover.

\section{Root classification}

Several different systems have been employed to classify roots. One common system divides roots on the basis of the order they arise from a primary root, $e . g$., first order lateral producing a second order lateral, etc ${ }^{44}$. Roots providing structural support for the tree may be termed long lateral roots (or any of 20 or more other names) while the roots sometimes suggested as functioning in the absorption of water and nutrients may be called short roots and are very often mycorrhizal ${ }^{44}$. Among the conifers, short roots are found throughout genera in the Pinaceae but not in the Cupressaceae ${ }^{44}$. Lateral roots may be classified into 
large and fine roots on the basis of diameter. There is no established convention defining the diameter size range of fine roots, although many biomass studies use $5 \mathrm{~mm}$ or $2 \mathrm{~mm}$ as the upper limit in diameter ${ }^{43}$. Some researchers further subdivide fine roots into a number of size classes: $2-5 \mathrm{~mm}$ in diam, less than $2 \mathrm{~mm}$ in diam, less than $1 \mathrm{~mm}$ in diam, etc.

Mycorrhizae should be treated as a separate class of roots because they result from a mutualistic symbiotic association between a host and a fungus and have a profound effect on fleshiness, amount and type of branching, rate of elongation, root hair formation, and suberization. Beyond the morphological and anatomical differences, mycorrhizae play a major role in the mineral nutrition of trees and may confer disease or drought resistance ${ }^{45}$. The association between host and fungus in mycorrhizae is so integrated that complete separation of the host and fungus is virtually impossible. In ectomycorrhizae, the most common type in the Pinaceae, short roots are covered with a mantle of hyphae of variable thickness from which hyphae extend out into the soil and intercellularly into the primary cortex to form a Hartig net. An individual hypha may extend more than $2 \mathrm{~m}$ from a mycorrhiza and form more than 120 lateral branches; 200 to over 2000 individual hyphae have been counted emerging from a single mycorrhiza ${ }^{45}$. From the standpoint of function, mycorrhizae are extensions of the plant root system greatly extending the region of nutrient absorption beyond the $1-2 \mathrm{~mm}$ zone generally ascribed to roots ${ }^{38}$.

Endomycorrhizae are found in the Cupressaceae and Taxodiaceae, and have relatively few external hyphae and root hairs near the apex of infected roots ${ }^{45}$. Estimates of endomycorrhizal biomass in coniferous forests have not been reported, although there are values for fine root biomass (diam $<2 \mathrm{~mm}$ ) for Cryptomeria (Taxodiaceae) and Chamacyparis (Cupressaceae) ${ }^{22}$.

\section{Structure of root systems}

The form and development of each root system is unique. Initial development appears to be under genetic control, although modified by soil (bulk density, moisture, temperature, texture, etc.) and plant factors (e.g., root competition, photosynthate availabilty, tree density) ${ }^{19,44}$. On level terrain, Douglas-fir first order lateral roots extend more or less equidistantly around the tree but asymmetrically on steeply sloping ground ${ }^{28}$. First order laterals in Douglas-fir may extend $2.5 \mathrm{~m}$ from the stem ${ }^{28}$. In large leaf pine, lateral roots may spread $14.3 \mathrm{~m}^{20}, 25 \mathrm{~m}$ for pines in sandy soils ${ }^{19}$.

Rooting density (root diam $>2 \mathrm{~mm}$ ) may reach 19 roots $/ 0.25 \mathrm{~m}^{2}$ in Douglasfir stands because of the spreading nature of the rooting systems, the extensive production of higher order laterals, and the intermingling of roots from different trees $^{28}$. Roots extend considerably beyond the width of the crown although rooting density decreases with distance from the stem ${ }^{19,33}$. Spatial variation in fine root (diam $<2 \mathrm{~mm}$ ) density has been reported independent of the proximity 
of stems ${ }^{31,33,43}$, although in a young Scots pine stand the largest amount of fine roots was 0.5 to $1.0 \mathrm{~m}$ from the stem ${ }^{33}$. Other studies indicate fine root biomass decreases with distance from the stem ${ }^{11,39}$.

Numerous studies have shown that most roots are found in the upper $50 \mathrm{~cm}$ of soil, and most root activity and mycorrhizae in the top $20 \mathrm{~cm}$ depending on soil aeration and fertility 9,19 . Roots have been found at depths of $6 \mathrm{~m}$ in sandy soils ${ }^{19}$ and ectomycorrhizae at depths of 1 to $3 \mathrm{~m}^{9}$. Localized concentration of roots may occur in decaying roots, channels formed by decaying roots, decaying logs, and thick litter layers ${ }^{15,28}$. Localized concentrations in more than one soil horizon may also occur due to fossil soil horizons ${ }^{19}$ or obstructions such as fragipan, bed rock, or cobbles and boulders ${ }^{24}$. Completion of the vertical expansion of the structural root system has been reported to require 30 years in a number of species, but may require 70 years in Scots pine ${ }^{19}$.

The problems inherent in the excavation of root systems have favored indirect methods for estimating root biomass. One commonly used method for large roots (diam $>10 \mathrm{~mm}$ ) is based on an allometric equation that relates root biomass to an easily measured tree parameter, e.g., diameter at breast height ${ }^{19.43}$. The applicability of such equations is probably restricted to similar conditions. Fine roots are usually lost during excavation of the trees used to develop the model. Soil cores have been utilized extensively to sample fine roots and circumvent the problems caused by excavation methods ${ }^{4}$. The usefulness of the coring method may be reduced if small diameter cores are used in soils with low rooting densities unless replication is increased.

Estimates of fine root and mycorrhiza biomass resulting from soil-coring methods are difficult to compare given the number of different methods employed to separate roots from cores. The main methods involve hand sorting, dry sieving, wet sieving, plus various permutations of these methods combined with magnification, and air or water separation of organic matter ${ }^{10,12,23,27,33,43}$. A number of procedural and reporting problems hinder comparisons of the results of these different methods. Root tip numbers have been reported without an associated biomass conversion factor. Differences exist in the depth of soil sampled, phenological status of the stand (often not stated), stand age, tree density (often not stated), size and functional classification of roots, and uncertainty about the efficiency of different sampling methods. Consider the efficiency of different methods for recovering mycorrhizae. Many ectomycorrhizae range in size from 0.5 to $3.0 \mathrm{~mm}$ long and from 0.15 to $0.6 \mathrm{~mm}$ in diam ${ }^{9}$. Consequently, researchers using screens with openings larger than $0.5 \mathrm{~mm}$ may not recover all of the mycorrhizae, a common problem ${ }^{15,29,30,46}$. Some researchers have deliberately discarded mycorrhizae before weighing fine roots $^{31,41}$, and other have been ambiguous about the method used ${ }^{34}$ or fail to state mesh size ${ }^{13}$. An additional problem arises when only 'active' mycorrhiza biomass is reported without the proportion of total mycorrhiza biomass this fraction represents being stated ${ }^{15,16,46}$ or total mycorrhiza biomass alone presented $^{9,10}$. 
Table 1 . Increase in estimated root biomass after soil samples previously hand-sorted at $7 x$ magnification were wet sieved. Cores extracted 23 May 1982 in a 35 year-old Pinus strobus stand near Ann Arbor, MI

\begin{tabular}{llll}
\hline \multirow{2}{*}{ Method } & Core & \multicolumn{2}{l}{ Kg roots per ha $(\%$ total $)$} \\
\cline { 3 - 4 } & & $2-5$ mm dia. & $<2$ mm. dia. ${ }^{b}$ \\
\hline Hand-sort & 1 & $5,986(100)$ & $7,378(69)$ \\
& 2 & $2,389(97)$ & $5,970(60)$ \\
Wet sieve $^{\mathrm{a}}$ & 1 & $0(0)$ & $3,351(31)$ \\
& 2 & $74(3)$ & $4,053(40)$ \\
\hline
\end{tabular}

${ }^{2}$ method of Fogel and Hunt ${ }^{10}$

${ }^{b}$ includes mycorrhizae

Is wet sieving more efficient than hand sorting for estimating root biomass? Cores were removed from the top $30 \mathrm{~cm}$ of soil in a white pine plantation. After the soil was screened $(2 \mathrm{~mm})$, roots were hand sorted at $7 \times$ magnification then wet sieved ${ }^{10}$ to recover any roots missed during hand sorting. Results (Table 1) clearly indicate that hand sorting is adequate for roots 2 to $5 \mathrm{~mm}$ in diam, but that wet sieving produces a 30 to $40 \%$ increase in the biomass estimate for roots $<2 \mathrm{~mm}$ diam. Higher values of non-mycorrhizal fine roots (diam 0.4-3 mm) were also produced by wet sieving than by excavation in a radiata pine stand ${ }^{31}$. The effect of mesh size on recovery was also shown in tests where a third more roots were retained by a $0.53 \mathrm{~mm}$ screen than by a 0.91 screen $^{36}$. Clearly the method of root extraction from soil should be given careful consideration and the method selected carefully described in subsequent publication.

\section{Reported root biomass estimates}

The estimates available ${ }^{43}$ indicate that root biomass generally comprises 15 to $25 \%$ of total tree biomass in coniferous forests ${ }^{2,14,40}$, although individual estimates range from 9 to 44 percent. Root biomass estimates for conifer stands less than 200 years old range from 3 to $85 \mathrm{Mg} / \mathrm{ha}$; an estimated $209 \mathrm{Mg} / \mathrm{ha}$ has been reported for an old growth Douglas-fir stand ${ }^{43}$. Reported fine root biomass estimates ${ }^{43}$ range from 1 to $12.6 \mathrm{Mg} /$ ha with a mean of $5 \mathrm{Mg}$. It is unclear but highly likely that mycorrhizae have not been included in these estimates. Mycorrhiza account for an additional $8 \%$ of total tree biomass in young Douglas-fir stands ${ }^{10}$. Given the large input of fine roots and mycorrhizae to the decomposition process ${ }^{8,10,13}$, it is crucial to determine mycorrhiza biomass. Unfortunately, the few published estimates available (Table 2) illustrate the difficulties in comparing different studies. The biomass of Douglas-fir (Pseudotsuga menziesii) mycorrhizae appears to be much larger than that of pine 


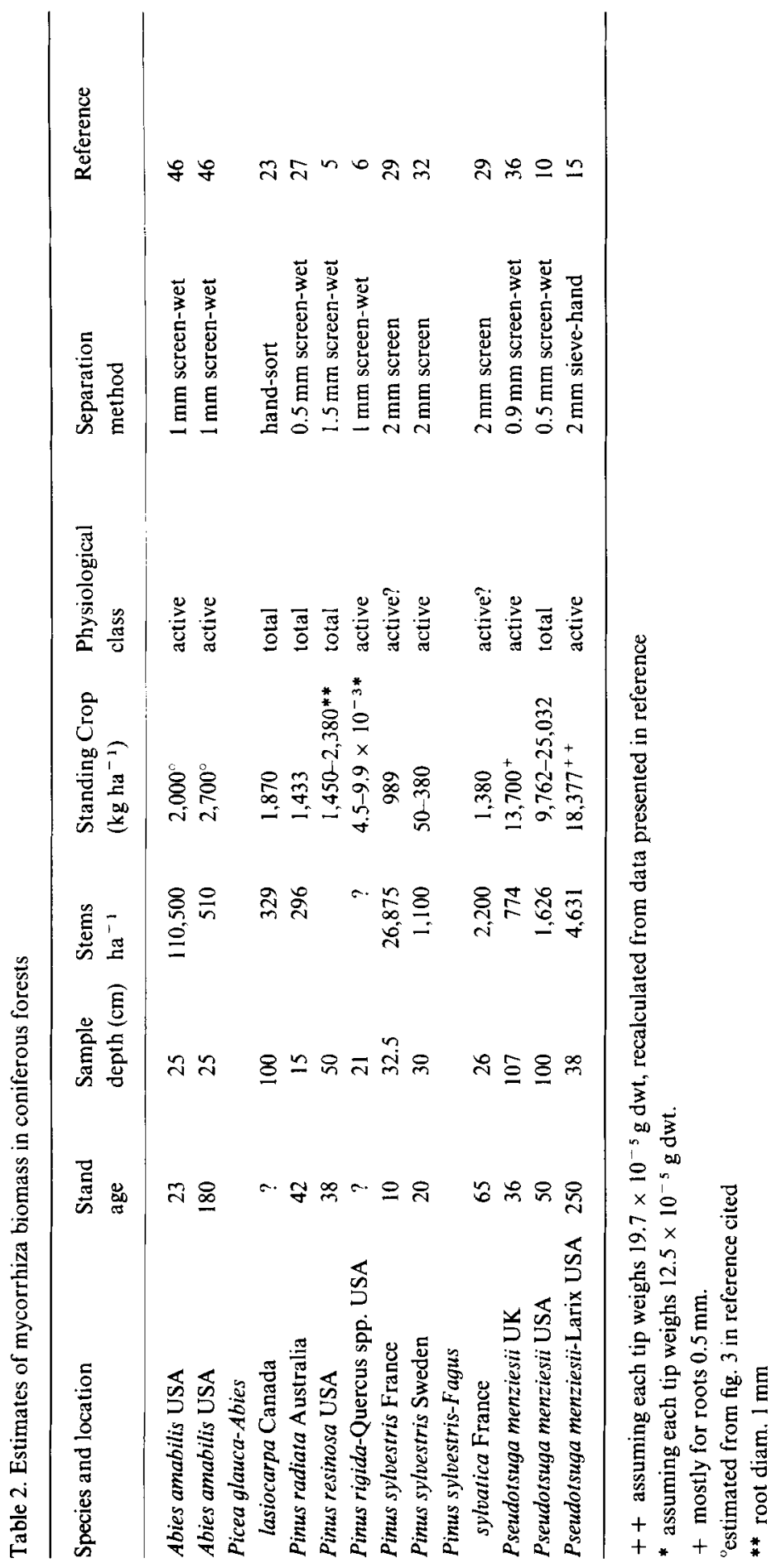


Table 3. Comparison of fine root biomass in stands of different species composition near Ann Arbor, Michigan

\begin{tabular}{|c|c|c|c|c|c|}
\hline \multirow[t]{2}{*}{ Species } & \multirow[t]{2}{*}{ Site } & \multirow{2}{*}{$\begin{array}{l}\text { Stand } \\
\text { age }\end{array}$} & \multicolumn{3}{|c|}{$\mathrm{Kg}$ roots per ha in top $30 \mathrm{~cm}$ of soil } \\
\hline & & & $\begin{array}{l}<2 \mathrm{~mm} \text { dia. } \\
(\% \text { total })\end{array}$ & $\begin{array}{l}\text { mycorrhizae } \\
\text { (\% total) }\end{array}$ & $\begin{array}{l}\text { total fine } \\
\text { roots }\end{array}$ \\
\hline \multirow[t]{2}{*}{ Pinus strobus } & Michigan $^{\mathrm{a}}$ & 35 & $11,750(94)$ & $736(6)$ & 12,486 \\
\hline & & & $15,815(95)$ & $900(5)$ & 16,715 \\
\hline Quercus/Carya & Michigan $^{\mathrm{a}}$ & 60 & $11,259(88)$ & $1,526(12)$ & 12,785 \\
\hline \multirow[t]{5}{*}{ Pseudotsuga menziesii } & Michigan $^{\mathrm{a}}$ & 30 & $1,661(22)$ & $5,978(78)$ & 7,639 \\
\hline & & & $2,760(33)$ & $5,491(67)$ & 8,251 \\
\hline & Oregon & 50 & & & \\
\hline & maximum $^{b}$ & & $11,916(49)$ & $12,199(51)$ & 24,115 \\
\hline & $\operatorname{minimum}^{\mathrm{b}}$ & & $1,948(29)$ & $4,752(71)$ & 6,700 \\
\hline
\end{tabular}

a same soil type, cores extracted 23 May-8 June 1982

${ }^{b}$ recalculated from Fogel and Hunt ${ }^{10}$

or spruce. The biomass of Abies mycorrhizae may be similar to Douglas-fir if the proportion of active to total mycorrhizae is the same (mean $=8 \%$ ) as measured for Douglas-fir (Fogel unpubl). The resulting standing crops in the 23 and 180 year-old Abies stands $(25.2$ and $34.0 \mathrm{Mg} / \mathrm{ha}$ ) compare very well to the 25.0 $\mathrm{Mg} / \mathrm{ha}$ reported for Douglas-fir ${ }^{10}$. Mycorrhiza biomass was compared in stands of mixed hardwood (Quercus and Carya dominates), white pine, and Douglas-fir growing on the same sandy glacial kame. Cores were extracted and wet sieved as described earlier ${ }^{10}$. The results of this study (Table 3 ) indicate that among the Michigan stands the Douglas-fir plantation has the smaliest fine root biomass, but has the largest biomass and proportion of mycorrhizae. The estimates for the Michigan Douglas-fir stand approximate the minimum standing crop reported for a similarly aged Douglas-fir stand in Oregon ${ }^{10}$.

\section{Root production and turnover}

Direct measurement of mycorrhiza and fine root production in established stands are extremely difficult in situ $^{39}$ and most studies have estimated production and turnover on the basis of changes in the biomass of various fractions over a given period. No significant seasonal differences in the biomass of large conifer roots have apparently been detected ${ }^{28,32,43}$. Several researchers have reported that $30-86 \%$ of the fine roots turnover annually ${ }^{10.32 .42}$, similar to the values reported for deciduous trees ${ }^{9}$. The large turnover in fine roots and mycorrhizae represents a considerable 'cost' to trees and constitutes a rather large sink of carbon, from 63 to $77 \%$ of total net primary production in coniferous forests ${ }^{1,14}$. These results indicate that roots are more important than 
leaf and branch litter in returning organic material to the soil, 4 to 5 times more material is returned by roots than by litter ${ }^{10,32}$. Studies in which root turnover has been assumed to contribute half as much as litter to the soil should be reexamined ${ }^{32,47}$.

The large turnover of mycorrhizae and fine roots results from grazing and/or senescence accompanied by decomposition. Estimates of total grazing do not exist although partial estimates indicate that soil fauna consume 0.3 to $10 \%$ of the estimated production of roots in temperate forests ${ }^{14,26}$. Senescence of fine roots has been attributed to stresses imposed on the root system by drought, periodic high water tables, extreme soil temperatures, defoliation, parasitism, over-fertilization, and in some instances by internal hormonal control 11,17,25,35,37,48.

The high turnover of fine roots has been explained as an 'adaptive strategy'. Root sloughing, with subsequent microbial immobilization, could help retain nutrients in the upper soil horizons when the tree is under stress ${ }^{14}$. Reynolds ${ }^{37}$ has calculated that during drought, roots consume energy reserves in one week equivalent to their own dry weight. This high 'cost' for maintenance respiration would make it 'advantageous' for a tree to maintain a small mass of roots during periods of stress. Withdrawal of essential nutrients just prior to root senescence, analogous to deciduous leaves, is an attractive hypothesis that deserves study. The rate of withdrawal, however, is important because this mechanism requires the tree to be stress tolerant thereby reducing its capacity for stress avoidance.

A second explanation is based on the assumption that most absorption of water and nutrients occurs immediately behind the root apex ${ }^{37}$ and that localized regions of water and nutrient depletion occur in soil. If this were the case shedding roots in depleted zones would avoid the high costs of respiration allowing new roots to exploit untapped soil zones for water and nutrients ${ }^{7,37}$. This explanation fails to take into account the role of mycorrhizal fungi in extending the absorption zone of roots beyond the $1-2 \mathrm{~mm}$ zone generally ascribed to roots ${ }^{38}$.

Given the importance of roots in primary production and the difficulties in estimating biomass, it is important to examine the different assumptions made in deriving production and turnover estimates. A direct comparison of the three methods employed was attempted by utilizing monthly estimates of mycorrhiza biomass and decaying roots (generally included in biomass by most researchers) for a Douglas-fir ecosystem (Fogel unpubl, Fogel and Hunt ${ }^{10}$ ). The first method assumes an acceptable method of separating live (active) from dead (inactive) roots does not exist. Root production (growth) is calculated by summing the differences between significantly different peaks and throughs in monthly or seasonal biomass estimates ${ }^{10.13}$. Positive increments are used to estimate production and decrements the return to soil (throughput fide Fogel and Hunt $^{10}$ ). Calculated production in the Douglas-fir ecosystem totals $15.3 \mathrm{Mg} / \mathrm{ha}$ and throughput $14.6 \mathrm{Mg} / \mathrm{ha}$; mortality is not estimated by this approach. 
Method 2 for estimating production and turnover assumes that differences in standing crops are real even if they are not significantly different statistically ${ }^{32}$. No attempt is made in this approach to reconcile simultaneous changes in live and dead standing crops. Production and mortality are estimated as the sum of all positive increments, minus a correction factor, in the standing crops of live and dead root fractions respectively. A minimum estimate of production by this method is $2.4 \mathrm{Mg} / \mathrm{ha}$, mortality $37.0 \mathrm{~kg} / \mathrm{ha}$, and throughput $36.4 \mathrm{Mg} / \mathrm{ha}$.

Method 3 is similar to method 2, but adds the assumption that production and mortality occur simultaneously. Production, mortality, and throughput estimates are obtained by balancing changes in the standing crop of each root fraction during each sampling interval ${ }^{42}$. For example, if live root standing crop decreases $10 \mathrm{~kg} / \mathrm{ha}$ and dead root standing crop decreases $5 \mathrm{~kg}$, production would be $0 \mathrm{~kg}$, mortality would be $10 \mathrm{~kg}$, and throughput would be $15 \mathrm{~kg} / \mathrm{ha}$. Estimated production in the Douglas-fir ecosystem is $2.4 \mathrm{Mg} / \mathrm{ha}$, mortality $45.1 \mathrm{Mg} / \mathrm{ha}$, and throughput $46.9 \mathrm{Mg} / \mathrm{ha}$.

Methods 1 and 3 accurately estimate the measured total standing crop of mycorrhizae on the last sample date when throughout is subtracted from the sum of the initial standing crop, production, and mortality. Method 2 overestimates the final measured standing crop by $3 \mathrm{Mg}$. The production estimated by methods 2 and 3 is identical. Method 3 produces estimates $22 \%$ larger for mortality and $29 \%$ larger for throughput than method 2 . Santantonio ${ }^{42}$ reported differences in the estimates of method 3 compared to method 2 of $30-60 \%$ in production, $50-70 \%$ in mortality, and $50-65 \%$ in throughput. Method 1 yields what are generally regarded as conservative estimates because steady state conditions are assumed and mortality is not taken into account. Throughput estimated by the latter method is lower than those estimated by methods 2 and $3,40 \%$ and $31 \%$ respectively, but production is $530 \%$ larger than calculated by either of the other methods. The much larger production estimated by method 1 is due to the inclusion of mortality in the production estimate and perhaps an underestimation of the live biomass in methods 2 and 3 . Method 3 produces estimates very similar to those of method 1 if only the maximum and minima preceding and following the maximum are used in the calculation rather than all 12 monthly standing crops. All three methods of estimating production and turnover indicate large fluxes in mycorrhiza production are matched by almost equally large fluxes in throughput.

Resolution of the question of which of the three methods yields the best estimate of production will depend on obtaining accurate estimates of the quantities of live and dead mycorrhizae. In practice, it has been very difficult to distinguish live and dead mycorrhizae or for that matter roots and the possibility for individual errors is great ${ }^{4}$. The problem of classifying the physiological status of ectomycorrhizae is compounded by their small size and the possibility of host tissues continuing to be active after death of the fungal symbiont. Common 
criteria for characterizing live mycorrhizae include: turgidity, color, integrity of root apex, association with mycelia, hyphal strands, or rhizomorphs, and when sectioned, color of host tissues ${ }^{15}$. Generally no attempt is made to determine the proportion of live to dead mycorrhizae. Underestimates of live mycorrhiza biomass may result from partial separation from soil, errors in classifying the physiological status of individual mycorrhizae, and from improper handling. For example, exposure to dry air for only a few minutes is sufficient to make small roots shrivel and die ${ }^{24}$.

Vital stains have been used by several investigators in an attempt to avoid subjective use of morphological criteria in distinguishing live and dead roots. The stains employed have included 2, 3, 5-triphenyltetrazolium chloride, 2,3,4triphenyltetrazolium bromide, and congo red 4 .

Unfortunately, roots of various plant species react quite differently to staining. Thus, dye adsorption is apparently related to the physical properties of the roots as well as to root cation exchange capacity.

\section{References}

1 Ågren G 1, Axelsson B, Flower-Ellis J G, Linder S, Persson H, Staaf H and Troeng E 1980 Annual carbon budget for a young Scots pine. Ecol. Bull. Stockholm 32, 307-313.

2 Assmann E 1970 The Principles of Forest Yield Study. 1st English edition. Pergamon Press, New York, NY, $506 \mathrm{p}$.

3 Berndt H W and Gibbons R D 1958 Root distribution of some native trees and understorey plants growing on three sites within ponderosa pine watersheds in Colorado. U.S. Dep. Agr., For. Serv., Rocky Mountain For. Range Exp. Sta. Pap. No. 37.

4 Bohm W 1979 Methods of Studying Root Systems. Springer-Verlag, New York, NY. 188 p.

5 Braekke F H and Kozlowski T T 1977 Distribution and growth of roots in Pinus resinosa and Betula papyrifera stands. Medd. Nor. Inst. Skogforsoeksves. 33, 437-451.

6 Bucholz K and Motto $\mathrm{H} 1981$ Abundances and vertical distributions of mycorrhizae in plains and barrens forest soils from the New Jersey, USA, pine barrens. Bull. Torrey Bot. Club 108, 268-271.

7 Caldwell M M 1979 Root structure: The considerable cost of below-ground function. In Topics in Plant Population Biology. Eds. O T Solbrig, S Jain, G B Johnson and P H Raven. Columbia Univ. Press, New York, NY. pp 408-430.

8 Edwards N T and Harris W F 1977 Carbon cycling in a mixed deciduous forest floor. Ecology $58,431-437$.

9 Fogel R 1980 Mycorrhizae and nutrient cycling in natural forest ecosystems. New Phytol. 86, 199-212.

10 Fogel R and Hunt G 1979 Fungal and arboreal biomass in a western Oregon Douglas-fir ecosystem: Distribution patterns and turnover. Can. J. For. Res. 9, 245-256.

11 Ford E D and Deans J D 1977 Growth of Sitka spruce plantation: Spatial distribution and seasonal fluctuations of lengths, weights and carbohydrate concentrations of fine roots. Plant and Soil 47, 463-485.

12 Grier C G, Vogt K A, Keyes M R and Edmonds R L 1981 Biomass distribution and aboveand belowground production in young and mature Abies amabilis zone ecosystems of the Washington Cascades. Can. I. For. Res. 11, 155-167.

13 Harris, W F, Kinerson R S Jr and Edwards N T 1977 Comparison of belowground biomass of natural deciduous forest and loblolly pine plantations. Pedobiolobia 17, 369-381. 
14 Harris W F, Santantonio D and McGinty D 1980 The dynamic belowground ecosystem. In Forests: Fresh Perspectives from Ecosystem Analysis. Ed. R H Waring Oregon St. Univ. Press, Corvallis. pp 119-129.

15 Harvey A E, Larsen M J and Jurgensen M F 1976 Distribution of ectomycorrhizae in a mature Douglas-fir/larch forest soil in western Montana. For. Sci. 22, 393-398.

16 Harvey A E, Larsen M J and Jurgensen M F 1980 Partial cut harvesting and ectomycorrhizae: Early effects in Douglas-fir-larch forests of western Montana. Can. J. For. Res. 10, 436 440.

17 Head G C 1973 Shedding of roots. In Shedding of Plant Parts. Ed. T T Kozlowski. Academic Press, New York, NY.pp 237-293.

18 Heikurainen L 1957 Ueber Veraenderungen in den Wurzelverhaeltnissen der Kiefernbestaende auf Moorboeden im Laufe des Jahres. Acta For. Fenn. 65, 1-54.

19 Hermann R K 1977 Growth and production of tree roots: A review. In The Belowground Ecosystem: A Synthesis of Plant-Associated Processes. Ed. J K Marshall. Range Sci. Dep. Sci. Ser. No. 26, Colo. St. Univ., Ft. Collins, CO, pp 7-28.

20 Hodgkins E J and Nichols N G 1977 Extent of lateral roots in natural longleaf pine as related to position and age of trees. For. Sci. 23, 161-166.

21 Kalela E K 1954 Mäntysiemenpuiden ja-kuusikoiden juurisuhteista. Acta For. Fenn. 61, $1-16$.

22 Karizumi N 1977 Root biomass. In Primary Productivity of Japanese Forests. Eds. T Shidei and T Kira. Univ. Tokyo Press. Vol. 16, 45-52.

23 Kimmins J P and Hawkes B C 1978 Distribution and chemistry of fine roots in a white spruce subalpine fir stand in British Columbia: Implications for management. Can. J. For. Res. 8, 265279.

24 Lyford W H 1975 Rhizography of non-woody roots of trees in the forest floor. In The Development and Function of Roots. Eds. J G Torrey and D T Clarkson. Academic Press, New York, NY. pp 179-196.

25 Lyr H and Hoffman G 1967 Growth rates and growth periodicity of tree roots. In International Review of Forestry Research. Eds. J A Romberger and P Mikola. Academic Press, New York, NY. Vol. 2, pp 181-236.

26 Magnusson C and Schlenius B 1980 Root consumption in a 15-20 year old Scots pine stand with special regard to phytophagous nematodes. Ecol. Bull., Stockholm 32, 261-268.

27 Marks G C, Ditchburne N and Foster R C 1968 Quantitative estimate of mycorrhiza populations in radiata pine forests. Aust. For. 32, 26-38.

28 McMinn R G 1963 Characterization of Douglas-fir root systems. Can. J. Bot. 41, 105-122.

29 McQueen D R 1968 The quantitative distribution of absorbing roots of Pinus silvestris and Fagus sylvatica in a forest succession. Oecol. Plant. 3, 83-99.

30 McQueen D R 1973 Changes in understory vegetation and fine root quantity following thinning of 30-year Pinus radiata in central North Island, New Zealand. J. Appl. Ecol. 10, 13-21.

31 Moir W H and Bachelard E P 1969 Distribution of fine roots in three Pinus radiata stands near Canberra. Ecology 50, 658-662.

32 Persson H 1978 Root dynamics in a young Scots pine stand in central Sweden. Oikos 30, 508-519.

33 Persson H 1980 Spatial distribution of fine-root growth, mortality and decomposition in a young Scots pine stand in central Sweden. Oikos 34, 77-87.

34 Quesnel H J and Lavkulich L M 1981 Comparison of the chemical properties of forest floors, decaying wood, and fine roots in three ecosystems on Vancouver Island. Can. J. For. Res. 11, 215-217.

35 Redmond D R 1955 Mortality of rootlets in balsam fir defoliated by the spruce budworm. For. Sci. 5, 64-69.

36 Reynolds E R C 1970 Root distribution and the cause of its spatial variability in Pseudotsuga taxifolia (Poir.) Britt. Plant and Soil 32, 501-517. 
37 Reynolds E R C 1975 Tree rootlets and their distribution. In The Development and Function of Roots. Eds. J G Torrey and D T Clarkson. Academic Press, London. pp. 163-177.

38 Rhodes L H and Gerdemann J W 1975 Phosphate uptake zones of mycorrhizal and nonmycorrhizal onions. New Phytol. 75, 555-561.

39 Roberts J 1976 A study of the root distribution and growth in a Pinus silvestris L. (Scots pine) plantation in East Anglia. Plant and Soil 44, 607-621.

40 Rodin L E and Bazilevich N I 1967 Production and Mineral Cycling in Terrestrial Vegetation. Oliver and Boyd, London, $288 \mathrm{p}$.

41 Safford L O and Bell S 1972 Biomass of fine roots in a white spruce plantation. Can. J. For. Res. 2, 169-172.

42 Santantonio D 1979 Seasonal dynamics of fine roots in mature stands of Douglas-fir of different water regimes: A preliminary report. In Root Physiology and Symbiosis. Eds. A Riedacker and J Gagnaire-Michard. Proc. IUFRO Symp. Root Physiol. Symbiosis, Nancy, France, Sept. 1978. CNRF, Champenoux, France. Vol. 6.

43 Santantonio D, Hermann R K and Overton W S 1977 Root biomass studies in forest ecosystems. Pedobiologia 17, 1-31.

44 Sutton R F 1980 Root system morphogenesis. N.Z. J. For. Sci. 10, 264-292.

45 Trappe J M and Fogel R 1977 Ecosystematic functions of mycorrhizae. In The Belowground Ecosystem: A Synthesis of Plant-Associated Processes. Eds. J K Marshall. Range Sci. Dep. Sci. Ser. No. 26, Colo. St. Univ., Fort Collins. pp. 205-214.

46 Vogt K A, Edmonds R L, Grier C C and Piper S R 1980 Seasonal changes in mycorrhizal and fibrous-textured root biomass in 23- and 180-year-old Pacific silver fir stands in western Washington. Can. J. For. Res. 10, 523-529.

47 Whittaker R H and Marks P L 1975 Methods of assessing terrestrial productivity. In Primary Productivity of the Biosphere. Eds. H Leith and R H Whittaker. Ecol. Stud. 14, 55-118.

48 Zak B 1964 Role of mycorrhizae in root disease. Ann. Rev. Phytopathol. 2, 377-392. 